\title{
ELASTISITAS PERMINTAAN JASA TRANSPORTASI KERETA API DI KOTA MALANG
}

\author{
Oleh: \\ Tofan Lore Firmansyah \\ Staff PT. Kereta Api Indonesia \\ E-mail/No. Hp: - /081233260260
}

\begin{abstract}
Method which is used in this research technique analyse elasticity, technique analyse this represent technique with aim to to know how big mount elasticity request of train transportation service in Malang City. From result of examination obtained conclusion of cause the happening of Perfect Elasticity at Economic Class, because of low price storey of society tend to to chosen cheap price as according to its production level. So that in middle economic level downwards more opting society of Economic class train than Business class train and also Executive. Executive class pertained elastic in of perfection because of how price will buy. Because of the class have different level. In this class met many middle-weight consumer to to the. While Business class train is including level. Ing strata third class at Business class train reside in between Economic class and Executive class. So that at this class of diffraction enjoyed by class consumer to the and also class under.
\end{abstract}

Keywords: elasticity, transportation, and train

\section{PENDAHULUAN}

Dewasa ini semakin dirasakan bahwa dalam melakukan berbagai kegiatan sarana transportasi merupakan sarana yang sangat vital dalam memperlancar usaha, tidak dapat dipungkiri bahwa dalam melakukan kegiatan ekonomi dunia saat ini sangat bergantung pada transportasi. Tanpa adanya transportasi dalam kegiatan ekonomi sebagai sarana penunjang maka tentu saja tidak akan tercapai hasil yang memuaskan. Peranan jasa transportasi menjadi sangat penting bagi perekonomian dunia yang secara langsung mendukung bisnis internasional.

Begitu majunya teknologi di bidang transportasi dewasa ini, saranasarana pengangkutan semakin berkembang pesat. Demikian juga perusahaan-perusahaan di bidang transportasi semakin banyak bermunculan, baik itu perusahaan perseorangan maupun bersama yang bagi perusahaan sejenis akan mempertajam persaingan dalam menarik konsumen.

Melihat perubahan perilaku konsumen yang menginginkan serba cepat dan praktis, maka para pengusaha transportasi harus berusaha menyediakan jasa yang diharapkan dapat memenuhi kebutuhan konsumen yaitu dengan menyediakan berbagai saran dan prasarana yang memberikan kemudahankemudahan serta kenyamanan dalam transportasi.

Dalam menghadapi persaingan yang semakin tinggi dalam bidang transportasi dan komunikasi mengakibatkan perusahaan harus mempunyai strategi agar memiliki daya saing tinggi jangka panjang dalam menghadapi persaingan global. Hanya perusahan-perusahaan fleksibel dalam 
memenuhi kebutuhan konsumen yang akan mampu bertahan dan berkembang dalam menghadapi persaingan global yang tajam. Fleksibilitas merupakan tuntutan pasar yang senantiasa menghendaki perusahaan untuk mampu menghasilkan produk dan jasa yang memenuhi kebutuhan konsumen yang dinamis.

Keberadaan kereta api sebagai alat angkut di Indonesia, dimulai pada jaman kolonial Belanda tepatnya pada tanggal 17 Juni 1864 oleh Gubernur Jenderal Hindia Belanda, Mr. L.A.J Baron Sloet van den Beele, yang digunakan untuk kepentingan kolonial yaitu sebagai sarana logistik untuk kebutuhan strategi guna menunjang ekonomi pemerintah kolonial untuk mengekspor hasil-hasil perkebunan sebanyak-banyaknya. Semenjak saat itu transportasi kereta api sangat besar pengaruhnya dalam pengiriman barang maupun sebagai sarana bepergian masyarakat. Semakin lama keadaan kereta api di Indonesia semakin berkembang.

Seiring perkembangan jaman dan kemerdekaan kereta api dijadikan sebuah perusahaan oleh pemerintah. Yaitu Perusahaan Umum Kereta Api (PERUMKA) tetapi usia PERUMKA tidak bertahan lama, dikarenakan keinginan pemerintah melepaskan PERUMKA yang berupakan BUMN untuk menjadi perusahaan swasta. Tetapi dengan perubahan tersebut pemerintah tidak serta-merta melepaskan, tetapi tetap diawasi oleh pemerintah. Dengan kata lain PT. Kereta Api Indonesia ditujukan untuk meningkatkan alat transportasi tanpa dukungan dari pemerintah namun tetap dipantau oleh pemerintah.

PT. Kereta Api Indonesia (KAI) merupakan salah satu perusahaan yang bergerak dalam bidang jasa transportasi angkutan darat yang produk jasanya yaitu sarana transportasi kereta api, sarana tersebut banyak digunakan masyarakat Indonesia, bahkan merupakan salah satu sarana transportasi angkutan darat yang menjadi unggulan dan permintaan pasar terhadap jasa transportasi ini sangat tinggi. Untuk dapat bertahan dalam persaingan penyediaan jasa angkutan darat, PT. KAI harus mampu memenuhi kebutuhan pasar.

PT. Kereta Api Indonesia (KAI) sebagai perusahaan transportasi darat yang tentunya tidak dapat lepas dari persaingan yang ada saat ini. Meningkatnya intensitas persaingan dan jumlah pesaing menurut PT. KAI akan dapat diperkecil dengan selalu memperhatikan kebutuhan dan keinginan konsumen, serta berusaha memenuhi apa yang konsumen harapkan dengan cara yang lebih baik dari para pesaingnya.

Keputusan konsumen dalam menggunakan jasa angkutan darat khususnya kereta api, dalam hal ini penggunaan jasa angkutan darat (kereta api) di Stasiun Kota Baru Malang akan berpengaruh dan membawa dampak yang menguntungkan bagi pihak pengelola atau dalam hal ini PT. KAI. Karena permintaan pasar yang tinggi terhadap sarana transportasi darat di Kota Malang, khususnya kereta api, yang mengutamakan ketepatan waktu, kecepatan serta kenyamanan, maka PT. KAI melakukan diversifikasi usaha dengan mengadakan kereta api kelas Ekonomi, Bisnis, Eksekutif untuk memenuhi permintaan pasar.

Sehubungan dengan latar belakang di atas, maka dalam hal ini peneliti mencoba membuat perumusan masalah yang sedang diteliti, yaitu seberapa besar tingkat elastisitas permintaan jasa transportasi kereta api di Kota Malang.

\section{TINJAUAN PUSTAKA}

Salah satu karakteristik penting dari fungsi permintaan pasar adalah 
derajat kepekaan jumlah permintaan terhadap perubahan salah satu faktor yang mempengaruhinya. Ukuran derajat kepekaan ini disebut elastisitas. Terdapat beberapa konsep elastisitas yang berhubungan dengan permintaan.

Mubyarto (1997) mengatakan bahwa elastisitas hanya digunakan untuk mengukur besar kecilnya perubahan jumlah barang yang diminta konsumen sebagai akibat perubahan harga. Konsep ini menyatakan perbandingan antara persentase perubahan jumlah barang yang diminta dengan persentase perubahan harga dengan rumus:

$\mathrm{e}_{\mathrm{h}}=\frac{\% \text { perubahan jumlah barang y ang diminta }}{\% \text { perubahan harga }}$

Karena elastisitas ini merupakan rasio dari dua ukuran maka dengan persentase perubahan harga tertentu maka elastisitas akan besar atau kecil tergantung pada besar kecilnya persentase perubahan jumlah barang yang diminta. Makin besar nilai $\mathrm{e}_{\mathrm{h}}$ berarti permintaan makin elastis dan sebaliknya tidak atau kurang elastis bila $\mathrm{e}_{\mathrm{h}}$ kecil.

Menurut Boediono (1993), untuk menghitung elastisitas dapat dilakukan dengan dua cara, yaitu: pertama, Elastisitas pada satu titik di dalam kurva permintaan yang disebut point elasticity dengan rumus:

$\mathrm{e}_{\mathrm{h}}=\frac{\mathrm{dQ}}{\mathrm{dP}} \times \frac{\mathrm{P}}{\mathrm{Q}}=\frac{\mathrm{dQ} \cdot \mathrm{P}}{\mathrm{dP} \cdot \mathrm{Q}}$

di mana, dQ = perubahan jumlah yang diminta; $\mathrm{dP}=$ perubahan harga; $\mathrm{P}=$ harga barang; $\mathrm{Q}=$ jumlah barang.

Kedua, Elastisitas di antara dua titik pada kurva yang disebut arc elasticity dengan rumus:

$$
\mathrm{e}_{\mathrm{h}}=\frac{\mathrm{dQ}}{\mathrm{dP}} \times \frac{\mathrm{P}_{1}+\mathrm{P}_{2}}{\mathrm{Q}_{1}+\mathrm{Q}_{2}}
$$

di mana, $d Q=$ perubahan jumlah yang diminta; $\mathrm{dP}=$ perubahan harga; $\mathrm{P} 1=$ harga yang pertama; $\mathrm{P} 2$ = harga yang kedua; Q1 = jumlah yang pertama; Q2 = jumlah yang kedua.

Nilai $e_{h}$ penting bagi penjual karena adanya hubungan antara nilai $\mathrm{e}_{\mathrm{h}}$ dengan penerimaan penjualan total (total revenue), yaitu: pertama, Bila penurunan harga $1 \%$ menaikkan jumlah yang diminta lebih besar dari $1 \%$ (yaitu bila $\mathrm{e}_{\mathrm{h}}$ $>1$ ), maka total revenue (TR) yang diterima penjual menjadi lebih besar.

Kedua, Bila penurunan harga $1 \%$ menaikkan jumlah yang diminta sama dengan $1 \%$ (yaitu bila $\mathrm{e}_{\mathrm{h}}=1$ ), maka total revenue (TR) yang diterima penjual adalah tetap.

Ketiga, Bila penurunan harga $1 \%$ menaikkan jumlah yang diminta lebih kecil dari $1 \%$ (yaitu bila $e_{h}<1$ ), maka total revenue (TR) yang diterima penjual dengan adanya penurunan harga tersebut menjadi lebih kecil.

Dalam kehidupan sehari-hari suatu barang konsumsi biasanya tidak berdiri sendiri tetapi mempunyai hubungan yang erat dengan barang lain dalam fungsinya untuk memenuhi kebutuhan manusia. Barnag-barang tersebut dapat dipertukarkan. Karena manfaatnya yang dapat dipertukarkan ini, maka harga masing-masing juga berhubungan erat dan dalam keadaan yang demikian maka perubahan harga suatu barang akan mempengaruhi jumlah barang yang diminta juga jumlah permintaan barang yang lain. Elastisitas silang dinyatakan sebagai berikut:

$\mathrm{e}_{\mathrm{s}}=\frac{\text { Persentase perubahan jumlah y ang diminta atas barang } \mathrm{X}}{\text { Persentase perubahan harga barang } \mathrm{Y}}$

Elastisitas silang dapat bernilai negatif, nol atau positif yang berarti sebagai berikut 1) Jika elastisitas silang 
bernilai negatif, berarti barang $X$ dan barang $\mathrm{Y}$ merupakan barang komplementer. Dengan demikian kenaikan harga barang Y menyebabkan penurunan permintaan barang $\mathrm{X}$; 2) Jika elastisitas silang bernilai nol, berarti barang $\mathrm{X}$ tidak mempunyai hubungan dengan barang $Y$. Dengan demikian kenaikan harga barang $\mathrm{Y}$ tidak menyebabkan perubahan harga barang X. 3)Jika elastisitas silang bernilai positif, berarti barang $\mathrm{X}$ dan barang $\mathrm{Y}$ merupakan barang substitusi. Dengan demikian kenaikan harga barang $\mathrm{X}$ menyebabkan kenaikan permintaan barang Y.

Elastisitas pendapatan atas
permintaan (income elasticity of
demand) didefinisikan sebagai
perubahan jumlah barang yang diminta yang disebabkan oleh perubahan pendapatan dari konsumen, yang dirumuskan sebagai berikut:

$\mathrm{e}_{\mathrm{h}}=\frac{\text { Persentase perubahan jumlah barang y ang diminta }}{\text { Persentase perubahan pendapatan }}$

Elastisitas pendapatan ini juga dapat bernilai negatif, nol atau positif yang berarti 1)Jika elastisitas pendapatan bernilai negatif, berarti barang $X$ merupakan barang tunai nilai, artinya kenaikan pendapatan konsumen akan mengakibatkan penurunan jumlah barang yang diminta. 2)Jika elastisitas pendapatan bernilai nol, berarti barang $\mathrm{X}$ merupakan barang netral, artinya jika pendapatan mengalami kenaikan atau mengalami penurunan maka tidak berpengaruh terhadap jumlah permintaan akan barang tersebut. 3)Jika elastisitas pendapatan bernilai positif, berarti barang $\mathrm{X}$ adalah barang normal, artinya bahwa kenaikan pendapatan sama dengan kenaikan jumlah barang yang diminta.

Konsep elastisitas pendapatan atas permintaan ini penting sekali dalam ilmu ekonomi karena mampu menerangkan perbedaan perilaku ekonomi dari berbagai golongan pendapatan masyarakat dalam pembelian barangbarang. Untuk permintaan bahan makanan terutama air minum di Indonesia, pada umumnya makin tinggi pendapatan makin rendah elastisitasnya.

Elastisitas permintaan dapat dipengaruhi oleh berbagai faktor. Winardi (1993) menjelaskan terdapat beberapa faktor yang mempengaruhi besar kecilnya elastisitas permintaan. Elastisitas umumnya akan besar bila 1)Terdapat barang subsitusi yang baik.2)Harga barang relatif tinggi.3) Ada banyak kemungkinan-kemungkinan penggunaan lain

Dan elastisitas bernilai kecil karena Barang tersebut digunakan dalam kombinasi dengan barang-barang lain, Barang yang bersangkutan relatif terdapat dalam jumlah banyak, dan dengan harga-harga yang rendah, Untuk barang tersebut tidak terdapat barangbarang substitusi yang baik, dan barang tersebut sangat dibutuhkan.

Transportasi merupakan industri jasa yang mengemban fungsi pelayanan publik dan misi pembangunan nasional, yang secara umum menjalankan fungsi sebagai katalisator pendukung pertumbuhan ekonomi, pengembangan wilayah, dan pemersatu wilayah Negara Kesatuan Republik Indonesia (NKRI). Pembangunan transportasi berpedoman pada sistem transportasi nasional (Sistranas), diarahkan untuk mendukung perwujudan Indonesia yang lebih sejahtera sejalan dengan upaya perwujudan Indonesia yang aman dan damai serta adil dan demokratis.

Untuk mendukung perwujudan kesejahteraan masyarakat, penyelenggaraan transportasi berperan mendorong pemerataan pembangunan, melayani kebutuhan masyarakat luas baik di perkotaan maupun perdesaan dengan 
harga terjangkau, mendukung peningkatan kesejahteraan masyarakat di wilayah pedalaman dan terpencil, serta untuk melancarkan distribusi barang dan jasa dan mendorong pertumbuhan sektor-sektor ekonomi nasional.

Transportasi merupakan salah satu komponen yang mutlak penting bagi pencapaian tujuan pembangunan nasional masa kini dan mendatang. Berbagai studi telah menunjukkan bahwa negara-negara yang berhasil dalam pencapaian tujuan pembangunan adalah negara-negara yang memiliki sistem transportasi yang memadai dalam memenuhi kebutuhan dinamis penduduknya, vice versa. Namun demikian, agar pembangungan transportasi nasional lebih efisien, efektif dan memberikan nilai tambah bagi sektor lain serta tidak menimbulkan berbagai dampak negatif bagi masyarakat dan lingkungan, maka perlu disusun dan dirumuskan rencana pembangunannya. Salah satu bentuk rencana yang penting untuk disusun dan dirumuskan yakni rencana dalam penelitian dan pengembangan teknologi dan manajemen transportasi.

Pengembangan teknologi dan manajemen transportasi merupakan salah satu tugas penting yang harus dilakukan pemerintah dalam mencapai tujuan pembangunan nasional. Hal ini karena dengan adanya pengembangan teknologi dan manajemen transportasi, maka perpindahan dan pergerakan barangbarang, jasa dan penduduk dari satu tempat ke tempat lain dapat berjalan lebih cepat, efisien dan efektif. Bahkan Morlock (1980) dan Bruton (1985) secara lebih spesifik menegaskan bahwa:

"......advances in transport have made possible changes in the way we live and the way in which societies are organized, and

\section{thereby have influenced the development of civilization"}

Walaupun kemajuan transportasi ini memiliki korelasi erat dengan pembangunan peradaban, namun keberhasilannya sangat berkaitan erat dengan berbagai kompleksitas dari faktor-faktor lainnya, seperti kualitas, biaya dan tingkat pelayanan sistem transportasi itu sendiri. Tanpa perhatian terhadap faktor-faktor ini, maka hampir dipastikan kemajuan transportasi nasional dapat menimbulkan berbagai biaya sosial (social costs) baik berupa kecelakaan, kemacetan, kebisingan, dan polusi.

Secara umum, kendala yang dihadapi sektor transportasi meliputi kuantitas dan kapasitas prasarana dan sarana yang tidak memadai dan diperparah dengan terjadinya bencana alam, kelembagaan dan peraturan, sumber daya manusia, teknologi, pendanaan/investasi, serta manajemen, operasi dan pemeliharaan. Oleh karena itu, sasaran umum pembangunan transportasi dalam kurun lima tahun mendatang adalah: 1) meningkatnya kualitas dan kapasitas prasarana dan sarana; 2) meningkatnya kualitas pelayanan dan keselamatan transportasi; 3) meningkatnya kualitas penyelenggaraan transportasi yang berkesinambungan dan ramah lingkungan, sesuai dengan standar pelayanan yang dipersyaratkan; 4) meningkatnya mobilitas dan distribusi nasional dan wilayah; 5) meningkatnya pemerataan dan keadilan pelayanan transportasi antar golongan masyarakat dan antar wilayah, baik di perkotaan, perdesaan, maupun daerah terpencil dan perbatasan; 6) meningkatnya akuntabilitas pelayanan transportasi melalui pemantapan sistem transportasi nasional, wilayah dan lokal; dan 7) khusus untuk daerah-daerah yang 
terkena bencana nasional akan dilakukan program rehabilitasi sarana dan prasarana transportasi, pembinaan sumber daya manusia (SDM) yang terpadu dengan program-program sektorsektor lain serta rencana pengembangan wilayah.

Untuk mencapai sasaran di atas, maka disusun kebijakan umum pembangunan transportasi meliputi: 1) kebijakan pembangunan prasarana dan sarana transportasi; 2) meningkatkan keselamatan transportasi nasional secara terpadu; 3) meningkatkan mobilitas dan distribusi nasional; 4) pembangunan transportasi yang berkelanjutan; 5) pembangunan transportasi terpadu yang berbasis pengembangan wilayah; 6) peningkatan data dan informasi serta pengembangan audit prasarana dan sarana transportasi nasional; 7) pembangunan dan pemantapan sistem transportasi nasional, wilayah dan lokal secara bertahap dan terpadu; 8) restrukturisasi kelembagaan dan peraturan perundangan transportasi; 9) mendorong pengembangan industri jasa transportasi yang bersifat komersial dengan melibatkan peran serta swasta dan masyarakat serta peningkatan pembinaan pelaku transportasi nasional; dan 10) pemulihan jalur distribusi dan mobilisasi di wilayah-wilayah yang terkena dampak bencana nasional secara terpadu.

Moda transportasi terdiri dari moda transportasi jalan, kereta api, sungai, danau dan penyeberangan, laut dan udara, yang dapat membentuk jaringan transportasi, dengan karakteristik teknis yang berbeda, serta pemanfaatannya disesuaikan dengan kondisi geografis daerah layanan.

Transportasi antarmoda adalah transportasi penumpang dan atau barang yang menggunakan lebih dari satu moda transportasi dalam satu perjalanan yang berkesinambungan. multimoda adalah transportasi barang dengan menggunakan paling sedikit 2 (dua) moda transportasi yang berbeda, atas dasar satu kontrak yang menggunakan Dokumen Transportasi Multimoda dari suatu tempat barang diterima oleh operator transportasi multimoda ke suatu tempat yang ditentukan untuk penerimaan barang tersebut.

Sasaran pembangunan transportasi jalan adalah: 1) terpeliharanya dan meningkatnya daya dukung, kapasitas, dan kualitas pelayanan prasarana lalulintas angkutan jalan untuk daerah yang sudah berkembang; 2) meningkatnya aksesibilitas wilayah yang sedang dan belum berkembang; 3) terwujudnya kerjasama antar pemerintah, Badan Usaha Milik Negara (BUMN) dan swasta dalam penyelenggaraan pelayanan prasarana jalan; 4) menurunnya kecelakaan dan meningkatnya kualitas pelayanan angkutan dalam hal ketertiban, keamanan dan kenyamanan; 5) meningkatnya keterpaduan antar moda dan efisiensi dalam mendukung mobilitas manusia, barang dan jasa; 6) meningkatnya keterjangkauan pelayanan transportasi umum bagi masyarakat luas serta dukungan pelayanan transportasi jalan perintis di wilayah terpencil untuk mendukung pengembangan wilayah; 7) meningkatnya efisiensi dan efektivitas regulasi dan kelembagaan transportasi; 8) meningkatnya kesadaran masyarakat dalam bertransportasi; 9) penanganan dampak polusi udara dan pengembangan teknologi sarana yang ramah lingkungan; 10) terwujudnya penyelenggaraan angkutan perkotaan yang efisien, handal, ramah lingkungan dengan tarif terjangkau.

Sasaran pembangunan perkeretaapian diprioritaskan untuk meningkatkan kinerja pelayanan terutama keselamatan angkutan, melalui penurunan tingkat 
kecelakaan dan fatalitas akibat kecelakaan di perlintasan sebidang dengan jalan dan penanganan keamanan operasi pada sepanjang lintas utama yang padat, serta kelancaran mobilisasi angkutan barang dan jasa.

Secara garis besar sasaran pembangunan perkeretaapian adalah: 1) pulihnya kehandalan dengan prioritas jalur yang strategis dan padat; 2) optimal dan pulihnya jaringan yang ada; 3) berkembangnya jaringan baru dan peningkatan kapasitas; 4) revisi peraturan perundangan di bidang perkeretaapian; 5) meningkatnya kualitas perencanaan dan pendanaan; 6) meningkatnya peran pemerintah daerah, BUMN dan swasta dalam bidang perkeretaapian; 7) meningkatnya SDM dan penguasaan teknologi; 8) standarisasi perkeretaapian nasional secara terpadu agar kesinambungan investasi, operasi dan pemeliharaan prasarana dan sarana perkeretaapian nasional dapat tercapai secara efisien.

Sasaran pengembangan transporttasi antarmoda/ multimoda antara lain adalah terwujudnya pelayanan menerus (single seamless services) antarmoda transportasi yang terlibat dalam pelayanan transportasi penumpang dan barang tepat waktu dari pintu ke pintu. Pengembangan pelayanan transportasi penumpang dan barang dari pintu ke pintu diarahkan pada keterpaduan jaringan pelayanan dan jaringan prasarana transportasi antarmoda/multimoda yang efektif dan efisien dalam bentuk interkoneksi pada simpul transportasi yang berfungsi sebagai titik temu yang memfasilitasi alih moda yang dapat disebut sebagai terminal antarmoda (intermodal terminal) yang memberikan nilai tambah pada sektor lain.

Jaringan pelayanan transportasi antarmoda/multimoda diwujudkan melalui keterpaduan antar trayek/lin- tas/rute angkutan jalan, kereta api, sungai dan danau, penyeberangan, laut dan udara, dengan memperhatikan keunggulan moda berdasarkan kesesuaian teknologi dan karakteristik wilayah layanan, serta lintas tataran transportasi baik dalam Tatranas, Tatrawil, maupun Tatralok.

Pengembangan jaringan prasarana antarmoda untuk penumpang dan atau barang, dilakukan dengan memperhatikan keunggulan masing-masing moda transportasi, didasarkan pada konsep pengkombinasian antara moda utama, moda pengumpan dan moda lanjutan.

Kebijakan yang dijadikan pedoman untuk mencapai sasaran tersebut antara lain a)Standardisasi sarana dan prasarana untuk terwujudnya pelayanan menerus (single seamless services) antar moda transportasi. b)Penataan regulasi dan kelembagaan untuk mendukung penyelenggaraan transportasi antarmoda/multimoda yang efektif dan efisien.c)Meningkatkan kualitas pelayanan mengarah kepada penerapan sistem tiket terpadu/dokumen tunggal.

Berkaitan dengan Manajemen Transportasi permasalahan yang dihadapi anatara lain: pertama Rendahnya kualitas SDM sebagai pelaku transportasi. Kualitas SDM yang ada belum sesuai dengan perkembangan teknologi transportasi.

Kedua Kesisteman dan koordinasi antarmoda. Untuk mendukung penyelenggaraan transportasi antarmo$\mathrm{da} /$ multimoda yang effektif dan effisien, dibutuhkan suatu sistem transportasi yang terintegrasi, yang mencakup antara lain manajemen dan pengaturan jaringan transportasi multimoda/antarmoda, penerapan dokumen tunggal, dan sistem tiket terpadu.

Ketiga Ketidak seimbangan penggunaan dan ketersediaan sarana transportasi antarmoda juga cukup 
dominan. Untuk transportasi jalan, utamanya di daerah dengan koridor padat seperti pantai utara Jawa (Pantura), masalah utama adalah kelebihan permintaan daripada fasilitas yang tersedia. Sarana dan prasaran transportasi jalan sangat dipadati oleh angkutan barang maupun penumpang. Sebaliknya, untuk transportasi laut di koridor yang sama, fasilitas yang ada belum dimanfaatkan secara maksimal. Diperlukan estimasi arus pergerakan barang dan manusia. Untuk itu diperlukan suatu peta mobilitas orang dan barang yang secara akurat dapat memberikan gambaran tentang arus perpindahan orang dan barang pada waktu-waktu tertentu.

$$
\text { Terdapat cukup banyak }
$$

pendekatan konseptual yang akan menjadi acuan dalam perencanaan transportasi. Adapun yang akan dijelaskan berikut ini hanya merupakan pendekatan utama yang penting diperhatikan dalam pelaksanaan penelitian ini. Pada dasarnya, pendekatan utama berikut merupakan pendekatan yang saling terkait erat dan berhubungan, sehingga dalam implementasinya akan digunakan dalam satu kesatuan kerangka pendekatan.

Secara garis besar, konsep dasar penanganan pekerjaan akan diawali dari pemahaman terhadap issue permasalahan pokok yang menjadi latar belakang penelitian ini. Sehubungan dengan itu, pengelompokkan berbagai permasalahan yang ada tersebut menjadi 4 (empat) kategori, yakni 1) Permasalahan Kemacetan Lalu-lintas; 2) Permasalahan Penurunan Fungsi Jalan Arteri Primer; 3) Permasalahan Degradasi Lingkungan; 4) Permasalahan Sosial dan Kemiskinan.

Dalam rangka penanganan ke-4 kategori permasalahan tersebut, maka akan digunakan konsepsi pendekatan perencanaan transportasi dan tata ruang terpadu seperti disajikan pada gambar berikut.

Dalam mengidentifikasi, menganalisis dan merumuskan strategi, rencana dan program penanganan, maka perlu dipertimbangkan perihal manfaat setiap rencana/program yang diusulkan. Pertimbangan manfaat ekonomi ganda (multiplier effects approach) merupakan pendekatan atau kriteria yang penting diperhatikan di sini. Dalam pendekatan ini suatu rencana, program atau proyek dinilai prioritasnya, dimana yang memberikan manfaat ekonomi ganda merupakan prioritas yang paling tinggi.

Dengan demikian, suatu program yang dipilih tidak hanya memberikan manfaat hanya sesaat dengan jangkauan lokal saja, tetapi diharapkan dapat memberi manfaat yang berkelanjutan dengan jangkauan luas, sehingga akan terus bergulir bagaikan bola salju (snow bowling) yang semakin lama manfaatnya akan semakin membesar. Pemilihan program sangat menentukan seberapa jauh efek ekonomi ganda itu akan terjadi. Berdasarkan pendekatan ini, maka setiap rencana dan program penanganan Kawasan Koridor Pantura Jawa akan dipilih berdasarkan kriteria pioritas manfaat ekonomi ganda.

Pendekatan sumber daya (resources approach) merupakan suatu pendekatan yang mengandalkan ketersediaan sumber daya atau potensi wilayah setempat yang dapat digunakan atau perlu didukung pengembangannya melalui implementasi suatu rencana atau program. Umumnya hal ini jarang diperhatikan oleh pihak-pihak yang menentukan dalam perencanaan suatu kegiatan. Akibatnya adalah ketika suatu rencana, program atau proyek itu dilaksanakan dan dioperasikan, secara ekonomi tidak memberikan nilai tambah yang berarti bagi wilayah atau kawasan setempat. Hal ini tentu bertentangan 
dengan pendekatan manfaat ekonomi ganda.

Dalam banyak kasus selama ini masyarakat ibarat penonton yang menyaksikan pelaksanaan pembangunan di wilayahnya. Hal ini terjadi karena sifat dan format pembangunannya adalah "top-down". Maksudnya adalah mulai dari perencanaan, pelaksanaan hingga pengoperasiannya tanpa sedikitpun masyarakat atau Pemda setempat dilibatkan. Kalaupun mereka terlibat sekedar sebagai pekerja. Hal ini pada gilirannya membuat semakin jauhnya jarak antara pembangunan itu sendiri dengan masyarakat.

Pendekatan dengan pelibatan stakeholders (participation approach) daerah sangat menentukan keberhasilan implementasi program-program pembangunan. Untuk itu pelibatan stakeholders daerah mulai dari perumusan kebijakan dan penetapan rencana dan program penanganan sangat penting artinya.

\section{METODE PENELITIAN}

Untuk menganalisis permintaan jasa kereta api kelas Ekonomi, Bisnis dan Eksekutif di kota Malang, maka penulis menggunakan jenis data sekunder. Data tersebut bersifat time series yang diambil mulai tahun 2003 2008.

Data sekunder adalah data yang bukan diusahakan sendiri pengumpulannya oleh peneliti. Tujuan dari data sekunder : untuk bahan analisis secara kuantitatif terkait pengembangan pusat kegiatan ekonomi.

Dalam penelitian ini peneliti menggunakan teknik analisis elastisitas :

$\mathrm{E}=\frac{\% \Delta \mathrm{n}}{\% \Delta g}$

Dimana, E = Elastisitas permintaan jasa transportasi kereta api; $\Delta \mathrm{g}=$ Perubahan jumlah penumpang; $\Delta \mathrm{n}=$ Perubahan rata-rata harga.

Dengan ketentuan hasil elastisitas sebagai berikut 1) Jika nilai $\mathrm{E}>1$ disebut elastic Perubahan rata-rata harga tiket berpengaruh banyak terhadap permintaan jasa transportasi kereta api; 2) Jika nilai $\mathrm{E}<1$ maka disebut inelastic. Perubahan rata-rata harga tiket tidak banyak berpengaruh terhadap permintaan jasa transportasi kereta api; 3) Jika nilai $\mathrm{E}=1$ maka disebut unitary elastic. Perubahan rata-rata harga tiket berpengaruh terhadap permintaan jasa transportasi kereta api dalam proporsi yang sama; 4) Jika nilai $\mathrm{E}=0$ disebut in elastis sempurna. Perubahan rata-rata harga tiket tidak berpengaruh terhadap permintaan jasa transportasi kereta api; 5)Jika nilai $\mathrm{E}=\infty$ disebut elastis sempurna.Perubahan rata-rata harga tiket tidak berpengaruh terhadap permintaan jasa transportasi kereta api seberapa pun besarnya.

\section{PEMBAHASAN}

Dalam hal ini perubahan harga mempengaruhi jumlah permintaan jasa transportasi, Berdasarkan data pada dapat diketahui bahwa jumlah penumpang Eksekutif pada tahun 2004 mengalami penurunan sebesar 16.282 juta. Pada tahun 2005 terjadi peningkatan penumpang sebesar 15.250 juta, peningkatan juga terjadi terus menerus mulai tahun 2005 - 2008 . Selain itu pada penumpang kelas Bisnis juga mengalami hal yang serupa, yaitu penurunan pada tahun 2004 dan kenaikan yang sangat signifikan pada tahun $2005-2008$.

Pada kelas Ekonomi terjadi kenaikan jumlah penumpang pada tahun 2004 sebesar 391.406 juta, setelah itu pada tahun 2005 terjadi kemerosotan jumlah penumpang sebesar 469.363 juta. Dari data diatas dapat dilihat bahwa kenaikan harga tiket juga mempengaruhi 
permintaan akan jasa transportasi kereta api.

Berdasarkan Gambar 1 dapat diketahui bahwa kategori elastisitas permintaan jasa transportasi kereta api di Kota Malang, yaitu :

Elastis Dari hasil penilaian pada kelas Eksekutif didapatkan dua kategori elastis yaitu pada September 2006 dan Januari 2007.

Inelastis Dari hasil penilaian pada kelas Eksekutif pada tabel diatas dapat diketahui bahwa kategori inelastis terdapat pada tahun 2005 bulan Oktober serta Februari 2007.

Unitary Elastis Dari hasil penilaian pada kelas Eksekutif didapatkan satu kategori unitary elastis pada tahun 2003 bulan Januari.

In Elastis Sempurna Dari hasil penilaian kelas Eksekutif pada tabel diatas dapat diketahui kategori in elastis sempurna adalah tahun 2003 bulan Februari sampai Desember, 2004, 2005 bulan Januari sampai September, selanjutnya bulan November dan Desember 2005 juga termasuk is elastis sempurna. Pada tahun 2006 yang termasuk in elastis sempurna pada bulan Januari sampai Agustus selanjutnya pada bulan Oktober sampai Desember. Pada tahun 2007 yang termasuk in elastis sempurna yaitu pada bulan Maret sampai Desember. Sedangkan tahun 2008 dalam satu tahun termasuk in elastis sempurna.

Elastis Sempurna Dari hasil penilaian pada kelas Eksekutif tidak didapatkan satu pun yang termasuk kategori elastis sempurna.

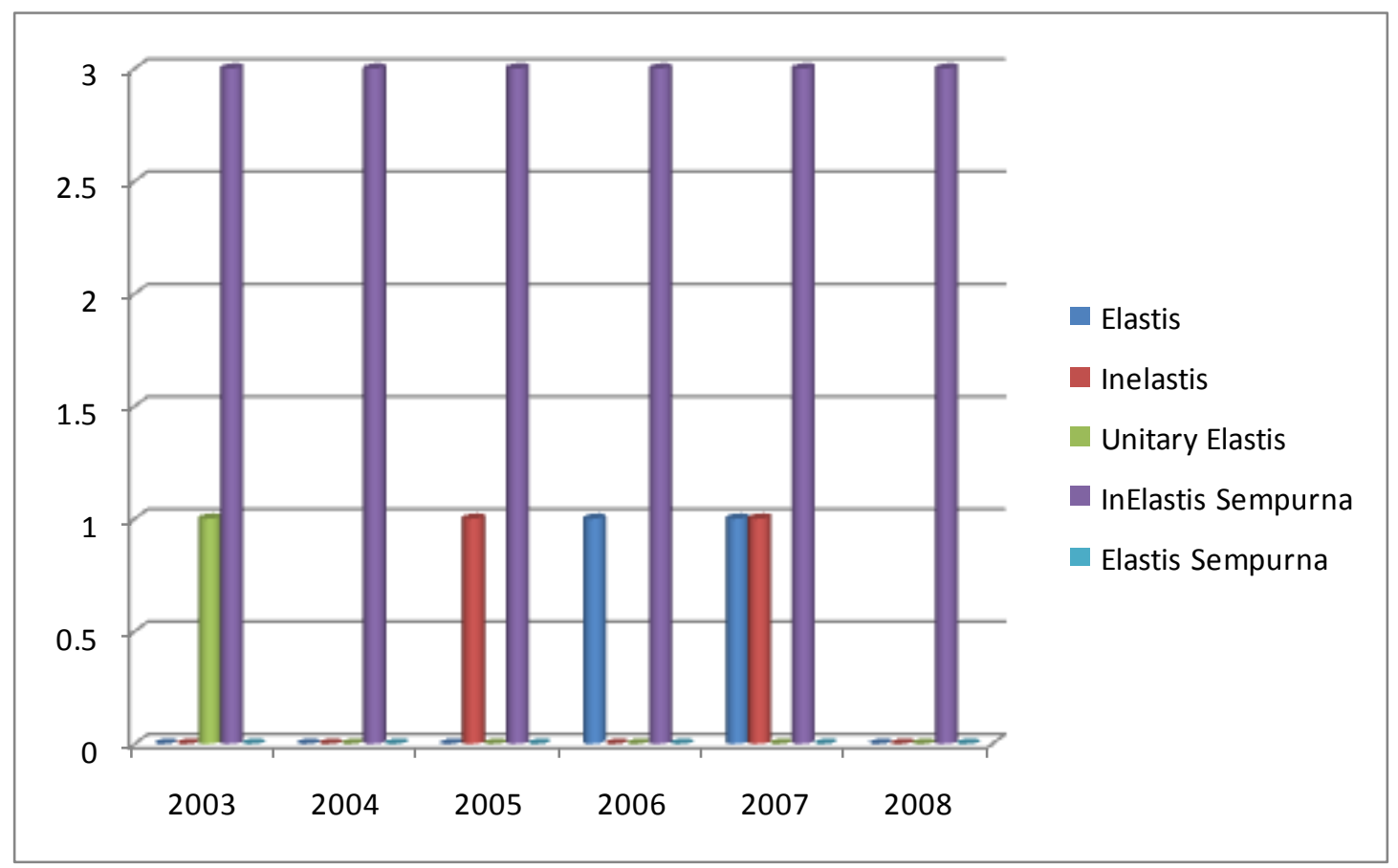

Gambar 1. Kategori Elastisitas Kereta Api Kelas Eksekutif di Kota Malang 


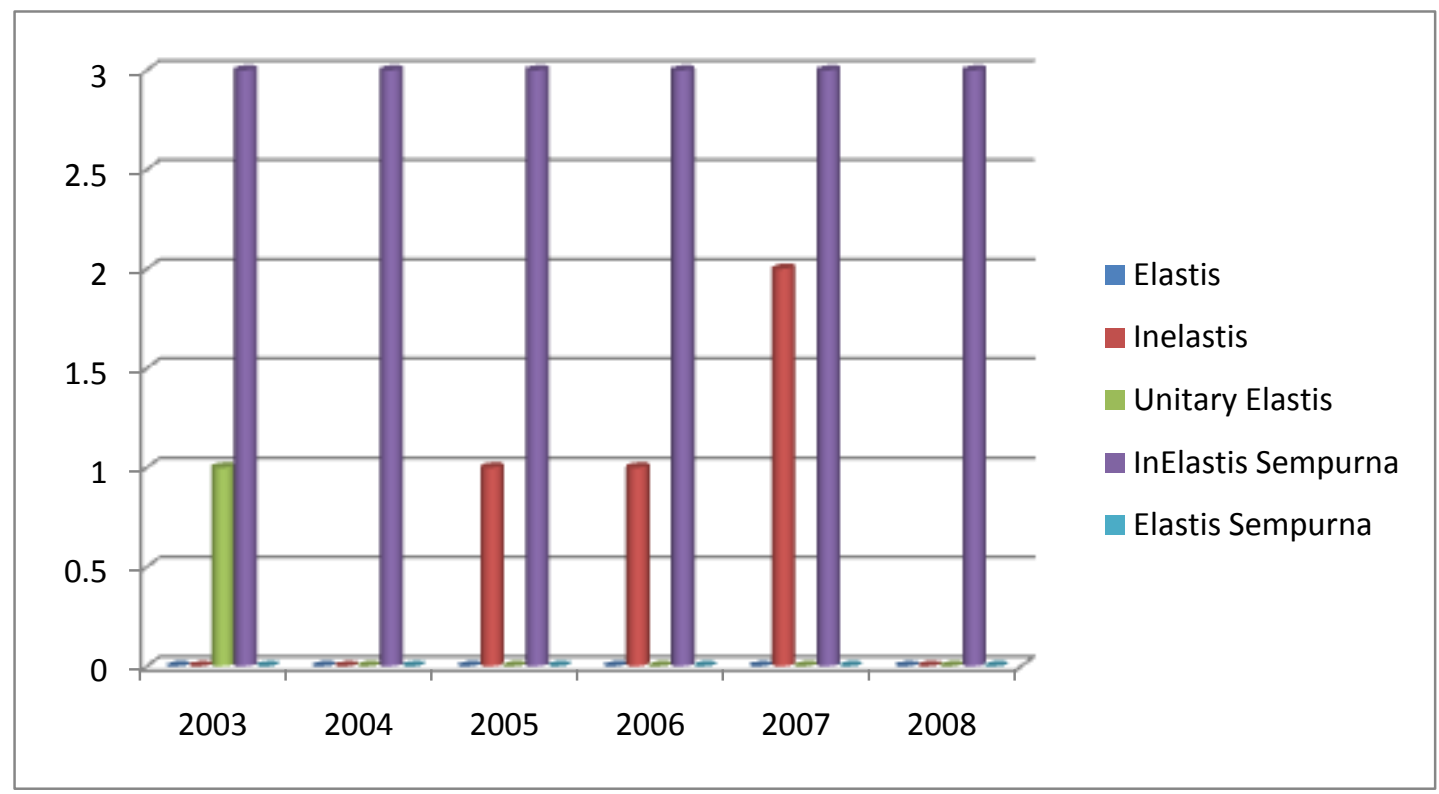

Gambar 2. Kategori Elastisitas Kereta Api Kelas Bisnis Di Kota Malang

Berdasarkan gambar 2. dapat diketahui bahwa kategori elastisitas permintaan jasa transportasi kereta api di Kota Malang, yaitu :

Elastis Dari hasil penilaian pada kelas Bisnis tidak didapatkan satu pun kategori elastis.

Inelastis Dari hasil penilaian pada kelas Bisnis pada tabel diatas dapat diketahui bahwa kategori inelastis terdapat pada tahun 2005 bulan Oktober dan September 2006.

Unitary Elastis Dari hasil penilaian pada kelas Bisnis didapatkan satu kategori unitary elastis pada tahun 2003 bulan Januari.

In Elastis Sempurna Dari hasil penilaian kelas Bisnis pada tabel diatas dapat diketahui kategori in elastis sempurna adalah tahun 2003 bulan Februari sampai Desember, 2004, 2005 bulan Januari sampai September, selanjutnya bulan November dan Desember 2005 juga termasuk is elastis sempurna. Pada tahun 2006 yang termasuk in elastis sempurna pada bulan Januari sampai Agustus selanjutnya pada bulan November sampai Desember. Pada tahun 2007 yang termasuk in elastis sempurna yaitu pada bulan Maret sampai Desember. Sedangkan tahun 2008 dalam satu tahun termasuk in elastis sempurna.

Elastis Sempurna Dari hasil penilaian pada kelas Eksekutif tidak didapatkan satu pun yang termasuk kategori elastis sempurna.

Berdasarkan Gambar 3 dapat diketahui bahwa kategori elastisitas permintaan jasa transportasi kereta api di kota malang, yaitu

Elastis Dari hasil penilaian pada kelas Ekonomi didapatkan satu kategori elastis yaitu pada bulan Desember 2004.

Inelastis Dari hasil penilaian pada kelas Ekonomi pada tabel diatas dapat diketahui bahwa kategori inelastis terdapat pada tahun 2005 bulan Oktober, September 2006 serta pada bulan Januari dan Februari 2007.

Unitary Elastis Dari hasil penilaian pada kelas Ekonomi didapatkan satu kategori unitary elastis pada tahun 2003 bulan Januari. 


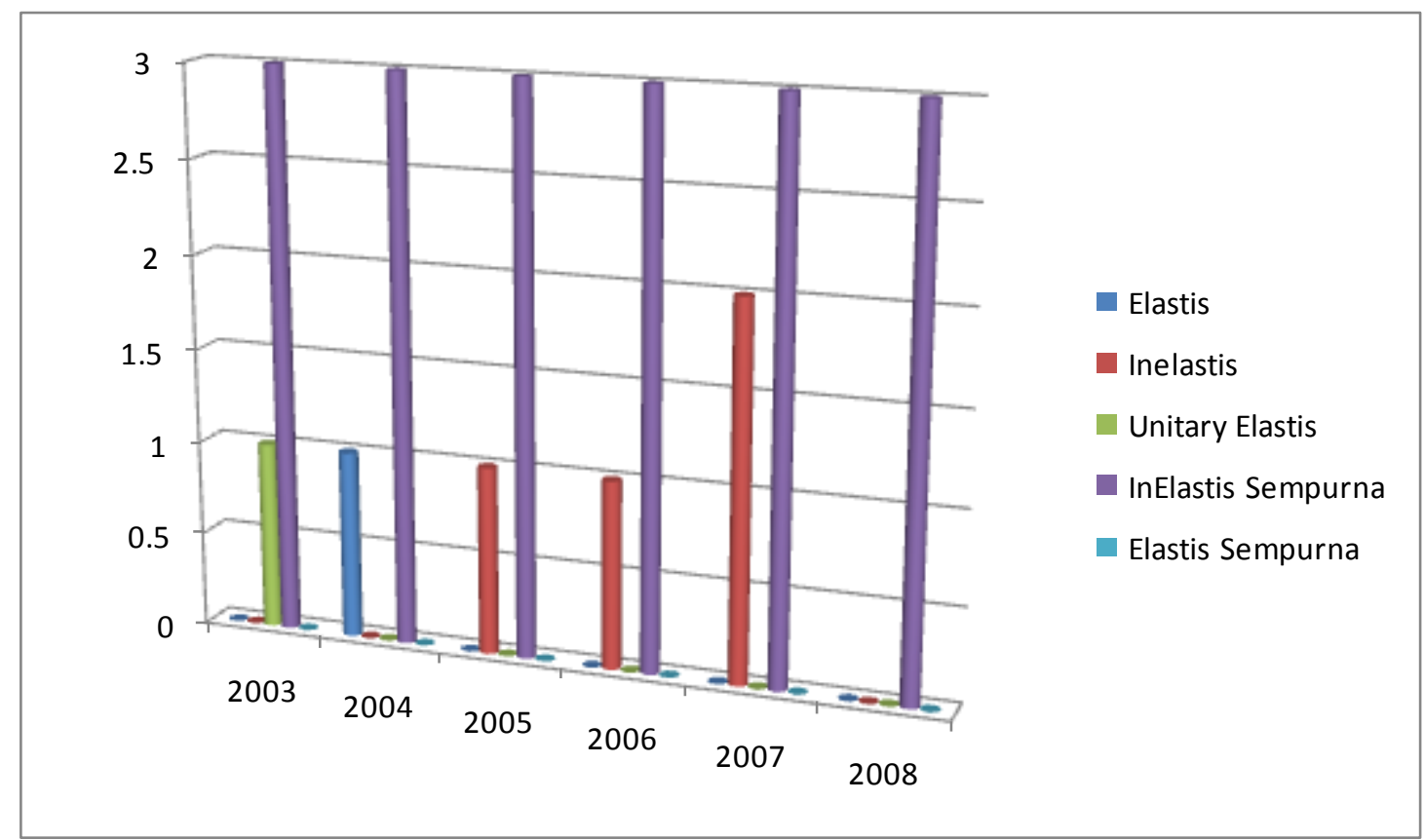

Gambar 3. Kategori Elastisitas Kereta Api Kelas Ekonomi Di Kota Malang

In Elastis Sempurna Dari hasil penilaian kelas Ekonomi pada tabel diatas dapat diketahui kategori in elastis sempurna adalah tahun 2003 bulan Februari sampai Desember, 2004 pada bulan Januari sampai November, 2005 bulan Januari sampai September, selanjutnya bulan November dan Desember 2005 juga termasuk is elastis sempurna. Pada tahun 2006 yang termasuk in elastis sempurna pada bulan Januari sampai Agustus selanjutnya pada bulan Oktober sampai Desember. Pada tahun 2007 yang termasuk in elastis sempurna yaitu pada bulan Maret sampai Desember. Sedangkan tahun 2008 dalam satu tahun termasuk in elastis sempurna.

Elastis Sempurna Dari hasil penilaian pada kelas Ekonomi tidak didapatkan satu pun yang termasuk kategori elastis sempurna.

\section{PENUTUP}

Dari hasil penelitian yang dilakukan maka penulis mengambil kesimpulan bahwa rata-rata harga mempengaruhi jumlah penumpang dalam proporsi yang sama. Hal ini dibuktikan dengan hasil penelitian yang menunjukkan bahwa 3 kelas dalam transportasi kereta api di Kota Malang didominasi oleh kategori In Elastis Sempurna.

Dari hasil penilaian kelas Eksekutif dapat diketahui kategori in elastis sempurna adalah tahun 2003 bulan Februari sampai Desember, 2004, 2005 bulan Januari sampai September, selanjutnya bulan November dan Desember 2005 juga termasuk is elastis sempurna. Pada tahun 2006 yang termasuk in elastis sempurna pada bulan Januari sampai Agustus selanjutnya pada bulan Oktober sampai Desember. Pada tahun 2007 yang termasuk in elastis sempurna yaitu pada bulan Maret sampai Desember. Sedangkan tahun 2008 dalam satu tahun termasuk in elastis sempurna.

Dari hasil penilaian kelas Bisnis dapat diketahui kategori in elastis sempurna adalah tahun 2003 bulan Februari sampai Desember, 2004, 2005 bulan Januari sampai September, selanjutnya bulan November dan Desember 2005 juga termasuk is elastis sempurna. Pada tahun 2006 yang 
termasuk in elastis sempurna pada bulan Januari sampai Agustus selanjutnya pada bulan November sampai Desember. Pada tahun 2007 yang termasuk in elastis sempurna yaitu pada bulan Maret sampai Desember. Sedangkan tahun 2008 dalam satu tahun termasuk in elastis sempurna.

Dari hasil penilaian kelas Ekonomi pada tabel diatas dapat diketahui kategori in elastis sempurna adalah tahun 2003 bulan Februari sampai Desember, 2004 pada bulan Januari sampai November, 2005 bulan Januari sampai September, selanjutnya bulan November dan Desember 2005 juga termasuk is elastis sempurna. Pada tahun 2006 yang termasuk in elastis sempurna pada bulan Januari sampai Agustus selanjutnya pada bulan Oktober sampai Desember. Pada tahun 2007 yang termasuk in elastis sempurna yaitu pada bulan Maret sampai Desember. Sedangkan tahun 2008 dalam satu tahun termasuk in elastis sempurna.

Dari hasil penelitian diatas dapat disimpulkan penyebab terjadinya Elastisitas Sempurna pada Kelas Ekonomi, dikarenakan pada tingkat harga yang rendah masyarakat cenderung memilih harga yang murah sesuai dengan tingkat penghasilannya. Sehingga dalam tingkatan ekonomi yang menengah ke bawah masyarakat lebih memilih kereta api kelas Ekonomi daripada kereta api kelas Bisnis maupun Eksekutif.

Pada kelas Eksekutif tergolong in elastis sempurna dikarenakan seberapa besarpun harga akan dibeli. Dikarenakan kelas tersebut mempunyai tingkatan yang berbeda. Dalam kelas ini banyak ditemui konsumen kelas menengah ke atas. Sedangkan pada kereta api kelas Bisnis termasuk pada tingkatan sedang. Dikarenakan strata pada ketiga kelas pada kereta api kelas Bisnis berada di antara kelas Ekonomi dan kelas Eksekutif. Sehingga pada kelas ini bias dinikmati oleh konsumen kelas atas maupun kelas bawah.

\section{DAFTAR PUSTAKA}

Arikunto, Suharsimi, 1993. Prosedur Penelitian. Cetakan Kelima. PT Rineka Cipta, Jakarta.

Basu Swasta dan Irawan, 1997. Manajemen Pemasaran Modern. Liberty, Yogyakarta.

Handoyo Wibisono, 1993. Manajemen Keuangan. Edisi Keenam. Erlangga, Jakarta.

Nuraini, Ida, 2001. Pengantar Ekonomi Mikro. UMM Pres, Malang.

Kotler, Philip, 1997. Manajemen Pemasaran. Buku Dua. Salemba Empat, Jakarta.

Lupiyoadi, Rambat, 2001. Manajemen Pemasaran dan Jasa. Teori dan Praktek, Edisi Pertama. Salemba Empat, Jakarta.

Miro, Fidel, Perencanaan Transportasi untuk Mahasiswa,Perencana, dan Praktisi. Penerbit Erlangga.

Mubyarto, 1991. Sistem dan Moral Ekonomi Indonesia. Yayasan LP3ES, Jakarta.

Sugioyono, 1999. Metode Penelitian Bisnis. Cetakan Ketiga. Alfabeta, Bandung.

Swasta, Basu, Drs., 1994. Azas-azas Marketing. Edisi ketiga. Liberty, Yogyakarta. 
Tamin, O.Z., Perencanaan Dan

Pemodelan Transportasi. Penerbit

ITB Bandung. 